\title{
EL SERVICIO PÚBLICO EN CUBA. UNA VISIŌN HACIA LA ACTIVIDAD \\ DEL EMPRESARIO MERCANTIL EN LA ACTUALIZACIÓN DEL MODELO ECONÓMICO
}

\author{
Yomisel Galindo Rodríguez (•) \\ Alcides F. Antúnez Sánchez (••) \\ Universidad de Granma (Cuba)
}

\begin{abstract}
RESUMEN
El tema de los senvicios públicos en Cuba resulta de extrema complejidad a partir de las transformaciones que ha sufrido el país en su modelo económi$\mathrm{co}$, así como sus condiciones socio-políticas. Esta investigación establece un primer acercamiento general en la relación de la actividad administrativa reconocida en la doctrina como servicio público y el derecho mercantil, con énfasis en las formas de empresarios — social e individual - reconocidas. En tal sentido se analizan los elementos doctrinales que conforman los servicios públicos, sus formas de gestión y control. Luego se analiza la situación cubana en torno a los senvicios públicos y su relación con la actividad mercantil sobre la base del nuevo modelo económico, político y social imperante en Cuba. De ahí se analizan un grupo de normas que posibiliten dicha relación y que muestran un futuro en la prestación de los servicios públicos en Cuba.
\end{abstract}

\section{PALABRAS CLAVE:}

administración pública, servicios públicos, empresario mercantil, Cuba.

\footnotetext{
(•)E-mail: ygalindor@udg.co.cu

(•.)E-mail: aantunez@udg.co.cu
}

\begin{abstract}
The issue about public service in Cuba has become extremely complex since the recent transformation occurred on the economic model, as well as in its socio-political conditions. This paper provides a general approach in the relation between the public administration recognized as public services and the commercial law emphasizing the different legal form of organizations -individual and collective - recognized by law. It is analyzed the doctrinal elements that shape the public services, its management and control. Then, it is analyzed the Cuban situation of the public services and its relation with the commercial law under a new economic, political and social model taking place in Cuba. Finally it is analyzed a bunch of norms that may make that relation possible in the near future in Cuba.
\end{abstract}

\section{KEY WORDS:}

public administration, public senvices, commercial law, Cuba.

RECEPCIÓN: 06/04/15

ACEPTACIÓN FINAL: 23/09/15 